\title{
Asticcacaulis benevestitus sp. nov., a psychrotolerant, dimorphic, prosthecate bacterium from tundra wetland soil
}

Correspondence Svetlana N. Dedysh dedysh@mail.ru

\author{
Lina V. Vasilyeva, ${ }^{1}$ Marina V. Omelchenko, ${ }^{1}$ Yulia Y. Berestovskaya, ${ }^{1}$ \\ Anatolii M. Lysenko, ${ }^{1}$ Wolf-Rainer Abraham, ${ }^{2}$ Svetlana N. Dedysh ${ }^{1}$ \\ and George A. Zavarzin ${ }^{1}$
}
${ }^{1}$ S. N. Winogradsky Institute of Microbiology, Russian Academy of Sciences, Prospect 60-let Octyabrya 7/2, Moscow 117312, Russia
${ }^{2}$ German Research Centre for Biotechnology, Chemical Microbiology, Mascheroder Weg 1, D-38124 Braunschweig, Germany

\begin{abstract}
A Gram-negative, aerobic, heterotrophic, non-pigmented, dimorphic prosthecate bacterium was isolated from tundra wetland soil and designated strain $\mathrm{Z}-0023^{\top}$. Cells of this strain had a dimorphic life cycle and developed a non-adhesive stalk at a site not coincident with the centre of the cell pole, a characteristic typical of representatives of the genus Asticcacaulis. A highly distinctive feature of cells of strain Z-0023 ${ }^{\top}$ was the presence of a conical, bell-shaped sheath when grown at low temperature. This prosthecate bacterium was a psychrotolerant, moderately acidophilic organism capable of growth between 4 and $28^{\circ} \mathrm{C}$ (optimum $15-20^{\circ} \mathrm{C}$ ) and between $\mathrm{pH} 4.5$ and 8.0 (optimum 5.6-6.0). The major phospholipid fatty acid was $18: 1 \omega 7 \mathrm{c}$ and the major phospholipids were phosphatidylglycerols. The $\mathrm{G}+\mathrm{C}$ content of the DNA was $60.4 \mathrm{~mol} \%$. On the basis of $16 \mathrm{~S}$ rRNA gene sequence similarity, strain $\mathrm{Z}-0023^{\top}$ was most closely related to Asticcacaulis biprosthecium (98\% similarity), Asticcacaulis taihuensis (98\%) and Asticcacaulis excentricus (95\%). However, low levels of DNA-DNA relatedness to these organisms and a number of distinctive features of the tundra wetland isolate indicated that it represented a novel species of the genus Asticcacaulis, for which the name Asticcacaulis benevestitus sp. nov. is proposed. The type strain is $\mathrm{Z}-0023^{\top}\left(=\mathrm{DSM} 16100^{\top}=\mathrm{ATCC}^{\mathrm{BAA}}-896^{\top}\right)$.
\end{abstract}

Dimorphic prosthecate bacteria (DPB) are present in almost any sample of freshwater or seawater and in many types of soils (Henrici \& Johnson, 1935; Poindexter, 1964, 1981a, 1999; Nikitin et al., 1966; Belyaev, 1968; Staley, 1968; Staley et al., 1987; Lapteva, 1987). An important characteristic of DPB is their ability to metabolize organic materials available in extremely low quantities and to tolerate prolonged periods of nutrient scarcity (Larson \& Pate, 1975; Poindexter, 1981b; Vasilyeva \& Zavarzin, 1995).

DPB are characterized by asymmetric cell reproduction. Each reproductive event in these bacteria produces two siblings: a sessile cell with a cellular stalk (a prostheca) and a motile cell with a polar flagellum. On the basis of the

Abbreviations: DPB, dimorphic prosthecate bacteria; FAMEs, fatty acid methyl esters.

The GenBank/EMBL/DDBJ accession number for the $16 \mathrm{~S}$ rRNA gene sequence of Z-0023 ${ }^{\top}$ is AM087199.

Tables showing data for utilization of carbon compounds, glycolipid and phospolipid fatty acid content, and polar lipid content of Asticcacaulis species are available as supplementary material in IJSEM Online. morphology of the reproductive stage (fission or budding), two fundamentally different types of DPB are distinguished: caulobacteria (Caulobacter, Brevundimonas, Maricaulis and Asticcacaulis) and hyphomicrobia (Hyphomicrobium, Pedomicrobium and Hyphomonas) (Poindexter, 1999; Abraham et al., 1999). Caulobacteria are especially widespread in environments where nutrient concentrations and ambient temperatures are low (Poindexter, 1981a, 1999; Staley et al., 1987). The taxonomy of caulobacteria has for many years relied primarily upon morphological criteria. Recently, a polyphasic approach, comprising 16S rRNA gene sequencing, lipid analysis and $\mathrm{NaCl}$ tolerance characterization, was used to analyse a large set of strains of these bacteria (Abraham et al., 1999, 2001). It has been shown that caulobacteria form two different phylogenetic lineages within the Alphaproteobacteria, one comprising the freshwater and brackish water representatives of the group Caulobacter-Brevundimonas-Asticcacaulis, and the other comprising the marine species of the genus Maricaulis.

All known representatives of the genus Asticcacaulis have been isolated from freshwater samples. Sessile cells of these 
bacteria develop subpolar or lateral prosthecae, which do not possess adhesive material at their tips. Instead, the cells bear holdfast material directly on their surfaces. At the time of writing, the genus comprised three recognized species, Asticcacaulis excentricus (Poindexter, 1964), Asticcacaulis biprosthecium (Pate et al., 1973) and Asticcacaulis taihuensis (Liu et al., 2005). Representatives of the genus Asticcacaulis are rarely observed and even more rarely isolated. In this report, we describe a novel species of the genus that has been isolated from tundra wetland peat.

The peat sample was collected from a depth of 3-6 cm of a shrub tundra wetland, north-east of Vorkuta in the Polar Urals of Russia $\left(68^{\circ} \mathrm{N} 52^{\circ} \mathrm{E}\right)$. One gram of peat was homogenized in $10 \mathrm{ml}$ sterile water, and $1 \mathrm{ml}$ of this suspension was used to inoculate $100 \mathrm{ml}$ of a liquid dilute peptone-yeast extract (PY) medium containing 0.005\% peptone and $0.005 \%$ yeast extract, $\mathrm{pH} 6 \cdot 8$, supplemented with $1 \%(\mathrm{v} / \mathrm{v})$ vitamin stock solution and $2 \%(\mathrm{v} / \mathrm{v})$ modified Hutner's basal salts as described by Staley (1968). For enrichment of psychrophilic bacteria, incubation was carried out for 2 months at $6{ }^{\circ} \mathrm{C}$. The resultant enriched cell suspension was spread-plated onto the surface of the PY medium supplemented with sodium acetate $(0 \cdot 1 \%, \mathrm{w} / \mathrm{v})$ and solidified with Difco agar $(2 \%, \mathrm{w} / \mathrm{v})$, and the plates were then further incubated at $6{ }^{\circ} \mathrm{C}$. As colonies became visible, they were successively restreaked onto fresh plates with the same agar medium until a culture with uniform colonies was obtained. This isolate, designated Z$0023^{\mathrm{T}}$, was maintained both on agar slants and in liquid cultures using the above-described PY medium with acetate (PY-A) and PYG medium $(0 \cdot 1 \%$ peptone, $0 \cdot 1 \%$ yeast extract, $0 \cdot 1 \%$ glucose, $\mathrm{pH} 6 \cdot 7)$. Cell morphology and cell life cycle, as well as culture purity, were examined by using phase-contrast and electron microscopy. In the latter case, the samples were stained with $1 \%(\mathrm{w} / \mathrm{v})$ uranyl acetate. For preparation of thin sections, cells were collected from agar plates and prefixed with $1.5 \%(\mathrm{w} / \mathrm{v})$ glutaraldehyde in $0.05 \mathrm{M}$ cacodylate buffer $(\mathrm{pH} 6 \cdot 5)$ for $1 \mathrm{~h}$ at $4{ }^{\circ} \mathrm{C}$ and then fixed in $1 \%(\mathrm{w} / \mathrm{v}) \mathrm{OsO}_{4}$ in the same buffer for $4 \mathrm{~h}$ at $20^{\circ} \mathrm{C}$. After dehydration in a graded series of ethanol, the samples were embedded in a Spurr epoxy resin. Thin sections were cut on an LKB-4800 microtome, and stained with $3 \%(\mathrm{w} / \mathrm{v})$ uranyl acetate in $70 \%(\mathrm{v} / \mathrm{v})$ ethanol. The specimen samples were examined with a JEM-100C transmission electron microscope. Growth of the isolate was monitored by nephelometry at $600 \mathrm{~nm}$ for 2-4 weeks in PY-A and PYG liquid media under a variety of conditions, including temperatures of $4-37^{\circ} \mathrm{C}, \mathrm{pH} 4 \cdot 5-8 \cdot 3$ and $\mathrm{NaCl}$ concentrations of $0 \cdot 1-5 \cdot 0 \%(\mathrm{w} / \mathrm{v})$. Variations in acidity level were achieved by mixing $0.05 \mathrm{M}$ solutions of $\mathrm{Na}_{2} \mathrm{HPO}_{4}$ and $\mathrm{KH}_{2} \mathrm{PO}_{4}$ to create media with the same ionic strength. To determine the range of potential growth substrates of strain $\mathrm{Z}-0023^{\mathrm{T}}$, the following carbon sources were tested using liquid PY medium with addition of the respective compounds at a concentration of $0 \cdot 1 \%(\mathrm{w} / \mathrm{v})$ : D-glucose, L-arabinose, D-ribose, D-xylose, D-galactose, D-fructose, lactose, D-maltose, sucrose, D-cellobiose, D-mannose,
D-melibiose, raffinose, L-rhamnose, D-trehalose, D-mannitol, D-sorbitol, starch, acetate, propionate, butyrate, pyruvate, malate, fumarate, succinate, citrate, methanol, ethanol, propanol, butanol, L-arginine, DL-alanine, Lphenylalanine, L-glutamate, L-lysine, L-proline, L-hydroxyproline, L-serine and L-tryptophan. Growth was examined after 8 days incubation at $20^{\circ} \mathrm{C}$. Sensitivity to antibiotics was tested by spreading 2-day-old cell suspension onto PYG agar medium and applying filter discs containing the following antibiotics: polymixin $\mathrm{M}(300 \mathrm{U})$, benzylpenicillin $(10 \mathrm{U})$, ristomycin $(30 \mu \mathrm{g})$, canomycin $(30 \mu \mathrm{g})$, monomycin $(30 \mu \mathrm{g})$, tetracycline $(30 \mu \mathrm{g})$, erythromycin $(15 \mu \mathrm{g})$, streptomycin $(30 \mu \mathrm{g})$ and levomycetin $(30 \mu \mathrm{g})$. Growth was assessed after 2 days incubation at $20^{\circ} \mathrm{C}$.

For fatty acid analyses, cells of strain Z-0023 ${ }^{\mathrm{T}}$ were grown on PYG agar plates at 10 and $20^{\circ} \mathrm{C}$. Cells were saponified [15\% $(w / v) \mathrm{NaOH}, 30 \mathrm{~min}, 100^{\circ} \mathrm{C}$, methylated to fatty acid methyl esters (FAMEs) (methanolic $\mathrm{HCl}, 10 \mathrm{~min}, 80^{\circ} \mathrm{C}$ ) and extracted [hexane/methyl tert-butyl ether $(1: 1, \mathrm{v} / \mathrm{v})$ ] as described in detail by Osterhout et al. (1991). FAMEs were analysed on a gas chromatograph equipped with a flameionization detector and an autosampler. Separation of FAMEs was achieved using a fused-silica capillary column $(25 \mathrm{~m} \times 0.2 \mathrm{~mm})$ with cross-linked $5 \%$ phenyl methyl silicone (film thickness $0.33 \mu \mathrm{m}$; HP Ultra 2). Injection temperature was $250{ }^{\circ} \mathrm{C}$ and detector temperature was $300{ }^{\circ} \mathrm{C}$. The oven programme was $150^{\circ} \mathrm{C}$ for $2 \mathrm{~min}$, then increased from 150 to $289^{\circ} \mathrm{C}$ at $4{ }^{\circ} \mathrm{C} \mathrm{min}{ }^{-1}$, followed by an isothermal period of $11 \mathrm{~min}$. The instrument was equipped with a flame-ionization detector and an autosampler; $\mathrm{H}_{2}$ served as the carrier gas. FAMEs were identified by comparison with standards or by GC-MS (Abraham et al., 1998). For polar lipid fatty acid analysis, lipids were extracted using a modified Bligh-Dyer procedure (Bligh \& Dyer, 1959) as described previously by Abraham et al. (1997). The extract of the total lipids was analysed by electrospray ionization using a quadrupole time-of-flight mass spectrometer (Yakimov et al., 2004).

Genomic DNA from strain Z-0023 ${ }^{\mathrm{T}}$ was extracted using an SDS-based assay as described by Dedysh et al. (1998). The DNA base composition of strain Z-0023 $3^{\mathrm{T}}$ was determined by thermal denaturation using a Unicam SP1800 spectrophotometer at a heating rate of $0.5^{\circ} \mathrm{C} \mathrm{min}^{-1}$. The $\mathrm{G}+\mathrm{C}$ value was calculated by using the equation of Owen et al. (1969): $\mathrm{G}+\mathrm{C} \quad(\%)=T_{\mathrm{m}} \times 2 \cdot 08-106 \cdot 4$. The DNA of Escherichia coli $\mathrm{K}-12$ was used as the standard. DNADNA hybridization experiments between strain Z-0023 ${ }^{\mathrm{T}}$ and two species of the genus Asticcacaulis, i.e. A. excentricus (DSM $4724^{\mathrm{T}}$ ) and A. biprosthecium (DSM $4723^{\mathrm{T}}$ ), were carried on nitrocellulose membrane filters (Hybond-N; Amersham International) according to Lysenko et al. (1988). The genome size of strain Z-0023 ${ }^{\mathrm{T}}$ was calculated by using the equation of De Ley et al. (1970): $M=[98.37-0.91 \times \mathrm{G}+\mathrm{C}(\%)] / k$, where $k$ is the DNA reassociation rate. PCR-mediated amplification of the $16 \mathrm{~S}$ rRNA gene from positions 28 to 1491 (numbering according 
to the International Union of Biochemistry nomenclature for E. coli $16 \mathrm{~S}$ rRNA) was performed using primers Eub9f and Eub1492r and reaction conditions described by Lane (1991). The 16S rRNA gene amplicons were purified using QIAquick spin columns (Qiagen) and sequenced on an ABI Prism 377 DNA sequencer using BigDye terminator chemistry, as specified by the manufacturer (PE Applied Biosystems). Phylogenetic analysis was carried out using the ARB program package (Ludwig et al., 2004).

Following growth on PY-A agar for 2 weeks at $6{ }^{\circ} \mathrm{C}$, small (1-2 $\mathrm{mm}$ in diameter), smooth, circular, convex with an entire edge, opaque, white colonies were observed. Single colonies were successively selected from plates for restreaking until a pure culture, designated $\mathrm{Z}-0023^{\mathrm{T}}$, was obtained. Microscopic examination revealed that cells of strain $\mathrm{Z}$ $0023^{\mathrm{T}}$ were Gram-negative, motile rods, $0 \cdot 5-0 \cdot 7 \mu \mathrm{m}$ in width and $1 \cdot 4-2 \cdot 0 \mu \mathrm{m}$ in length (Fig. 1a). These cells reproduced by binary fission and underwent a dimorphic life cycle during which a sessile cell with a cellular stalk (a prostheca) divided to give rise to a motile cell with a polar flagellum (Fig. 1b). A single, non-adhesive prostheca of these bacteria was $0 \cdot 10-0 \cdot 15 \mu \mathrm{m}$ in diameter and had an excentral, subpolar location on the cell (Fig. 1c, d), which is
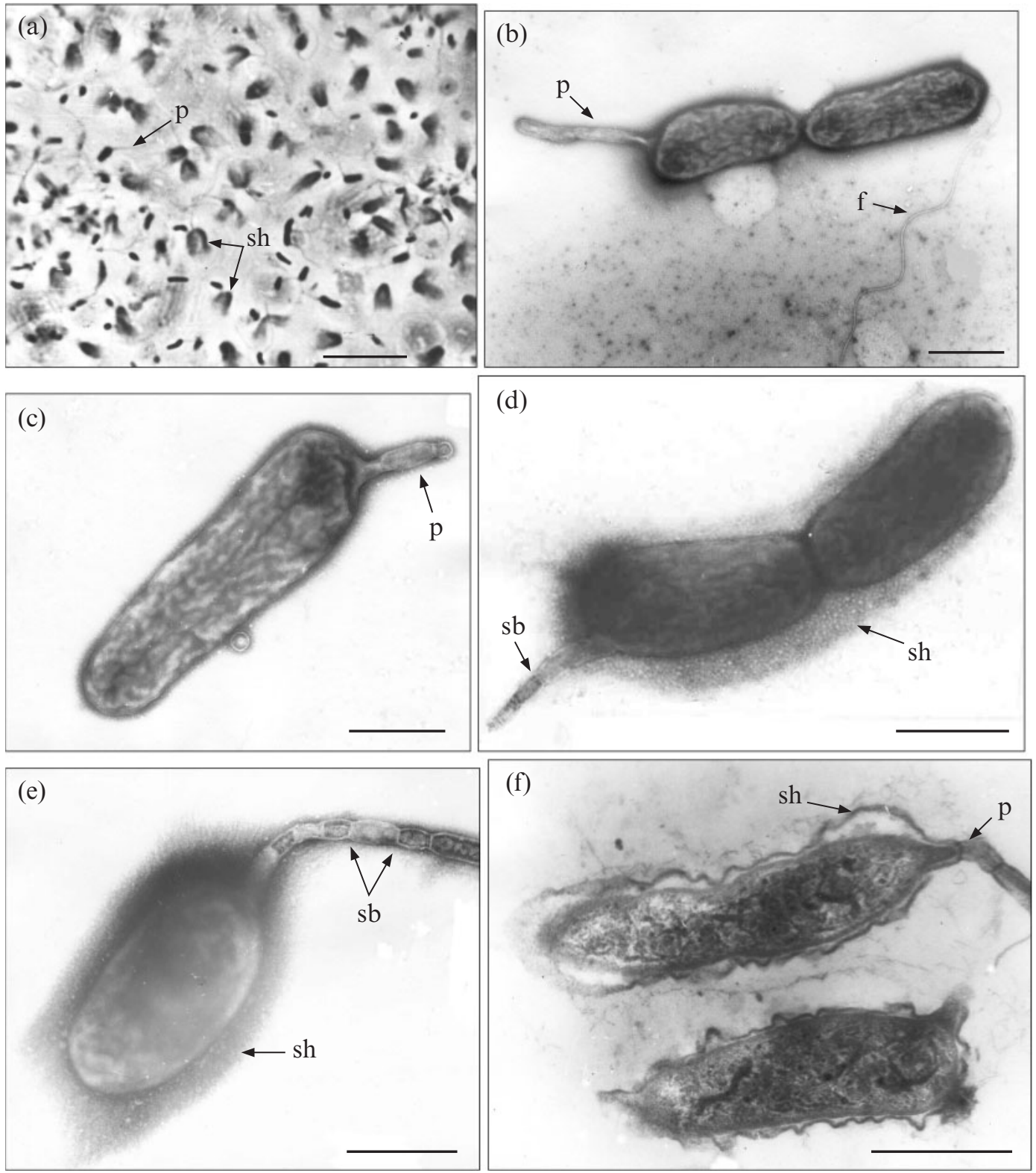

Fig. 1. (a) Phase-contrast micrograph of cells of strain Z-0023 $3^{\top}$ grown on PY-A medium for 3 weeks at $6{ }^{\circ} \mathrm{C}$. (b-e) Electron micrographs of cells of strain Z-0023 ${ }^{\top}$. (f) Electron micrograph of a section taken through the area of juncture of cell and prostheca of strain Z-0023 ${ }^{\top}$. Bars: (a), $10 \mu \mathrm{m}$; (b)-(f), $0.5 \mu \mathrm{m}$. p, Prostheca; f, flagellum; sh, sheath; sb, stalk bands. 
characteristic of representatives of the genus Asticcacaulis (Poindexter, 1964; Pate et al., 1973). Prostheca length ranged from 0.5 to $5.0 \mu \mathrm{m}$ depending on cultivation conditions; maximal length was attained in defined minimal media. In cells grown on rich complex media (e.g. PYG medium), prosthecae were short or were not observed, and the cells themselves appeared significantly elongated (up to 10 -fold) and misshapen.

The major distinctive feature of cells of strain Z-0023 ${ }^{\mathrm{T}}$ was the presence of a conical, bell-shaped sheath attached to the sessile cell at the point of juncture of prostheca and cell (Fig. 1d-f). Cell division occurred within this sheath (Fig. 1d). Interestingly, these clothes-like sheaths appeared on cells grown at low temperatures (below $10^{\circ} \mathrm{C}$ ) but not on cells grown at moderate temperatures $\left(15-25^{\circ} \mathrm{C}\right)$.

In stationary liquid cultures, most of the growth of strain Z$0023^{\mathrm{T}}$ occurred in the form of a pellicle that developed at the surface of the medium. In liquid cultures incubated on a rotary shaker, cells were evenly dispersed throughout the culture.

Similar to other known representatives of the genus Asticcacaulis, strain Z-0023 ${ }^{\mathrm{T}}$ was not capable of growth in a mineral medium with glucose or another compound as the only growth substrate. It had an absolute requirement for the presence of growth factors in cultivation media. Thus, utilization of a given carbon compound was assumed to have occurred when growth was distinctly improved in its presence compared with on basal PY medium alone. The carbon compounds tested and the results are presented in Supplementary Table S1 (available in IJSEM Online). Most sugars, ethanol and several organic acids (acetate, malate, fumarate and succinate) were the preferred growth substrates. Strain Z-0023 ${ }^{\mathrm{T}}$ differed from A. excentricus and A. biprosthecium by its inability to utilize pyruvate, and it could also be differentiated from A. taihuensis by its inability to utilize D-cellobiose, D-mannose and D-melibiose.

Strain $\mathrm{Z}-0023^{\mathrm{T}}$ grew in the $\mathrm{pH}$ range $4 \cdot 5-8 \cdot 3$ with the optimum at $\mathrm{pH} 5 \cdot 6-6 \cdot 0$. The temperature range for growth was $4-28^{\circ} \mathrm{C}$ with the optimum at $15-20^{\circ} \mathrm{C}$. The culture generation time under optimal temperature conditions, calculated from increases in $\mathrm{OD}_{600}$ in the exponential phase of growth, was in the range $30-35 \mathrm{~h}$. Both the specific growth rate and the growth yield of the culture at $25-28^{\circ} \mathrm{C}$ were significantly lower than those attained at $15-20^{\circ} \mathrm{C}$. No growth occurred at $37^{\circ} \mathrm{C}$.

Compared with A. excentricus DSM $4724^{\mathrm{T}}$ and $A$. biprosthecium DSM $4723^{\mathrm{T}}$ (Abraham et al., 2001), $\mathrm{NaCl}$ was not required for growth of strain $\mathrm{Z}-0023^{\mathrm{T}}$ and this isolate had less tolerance of dissolved salts. Growth inhibition of $50 \%$ was observed in the presence of $\mathrm{NaCl}$ in the medium at concentrations of $1-1.5 \%(\mathrm{w} / \mathrm{v})$, whereas $\mathrm{NaCl}$ at concentrations above $2 \cdot 0 \%$ completely inhibited growth. Strain $\mathrm{Z}-0023^{\mathrm{T}}$ was susceptible to antibiotics that inhibit prokaryotic protein synthesis, i.e. streptomycin, tetracycline, erythromycin, levomycetin and monomycin.
Whole-cell fatty acid content and comparison of glycolipid and phospholipid fatty acid profiles of strains $\mathrm{Z}-0023^{\mathrm{T}}, A$. biprosthecium DSM $4723^{\mathrm{T}}$, A. excentricus DSM $4724^{\mathrm{T}}$ and A. taihuensis $\mathrm{T} 3-\mathrm{B}^{\mathrm{T}}$ are shown in Table 1 and in Supplementary Table S2 in IJSEM Online, respectively. As with recognized members of the genus Asticcacaulis, $18: 1 \omega 7 c$ was the major fatty acid in strain $\mathrm{Z}-0023^{\mathrm{T}}$. The distinguishing feature of the fatty acid profile of strain Z$0023^{\mathrm{T}}$ was the absence of $12: 13-\mathrm{OH}$, which was considered to be a common feature of the FAME profiles in Asticcacaulis (Abraham et al., 2001). Glycolipids present in recognized Asticcacaulis species are $\alpha$-D-glucopyranosyl- and $\alpha$-Dglucopyranuronosyl-diacylglycerols, which are also common in Caulobacter, Brevundimonas and some other members of the Alphaproteobacteria. In strain $\mathrm{Z}-0023^{\mathrm{T}}$, four different glycolipids were detected, among them a compound of 796 Da previously detected in A. biprosthecium DSM $4723^{\mathrm{T}}$ but lacking in A. excentricus DSM $4724^{\mathrm{T}}$. The electrospray ionization mass spectra of the phospholipids of strain Z-0023 ${ }^{\mathrm{T}}$ showed clear differences from those of the other type strains (Supplementary Table S3 in IJSEM Online). Phospholipids of this bacterium were of the phosphatidylglycerol type and six different phospholipids could be identified, analogous to A. biprosthecium DSM $4723^{\mathrm{T}}$ and A. excentricus DSM $4724^{\mathrm{T}}$. Interestingly, most of the phospholipids detected in strain $\mathrm{Z}-0023^{\mathrm{T}}$ were also found in $A$. excentricus DSM $4724^{\mathrm{T}}$ but not in $A$. biprosthecium DSM $4723^{\mathrm{T}}$.

Comparative sequence analysis of the $16 \mathrm{~S}$ rRNA gene revealed that strain Z-0023 ${ }^{\mathrm{T}}$ belonged to the Alphaproteobacteria and,

Table 1. Whole-cell fatty acid content of the novel prosthecate isolate $\mathrm{Z}-0023^{\top}$ and other representatives of the genus Asticcacaulis

Taxa: $1, \mathrm{Z}-0023^{\mathrm{T}} ; 2$, A. biprosthecium; 3, A. excentricus; 4, A. taihuensis. Values shown are percentage of total fatty acids.

\begin{tabular}{|lcccc|}
\hline FAME & $\mathbf{1}$ & $\mathbf{2}$ & $\mathbf{3}$ & $\mathbf{4}$ \\
\hline $12: 0$ & - & $2 \cdot 5$ & - & - \\
$12: 03-\mathrm{OH}$ & - & - & - & $2 \cdot 3$ \\
$12: 13-\mathrm{OH}$ & - & $7 \cdot 5$ & $4 \cdot 2$ & $2 \cdot 6$ \\
$14: 0$ & - & $1 \cdot 1$ & - & $1 \cdot 1$ \\
$15: 0 \mathrm{a}$ & - & - & - & $2 \cdot 6$ \\
$15: 0$ & $3 \cdot 4$ & $2 \cdot 9$ & $2 \cdot 3$ & $1 \cdot 5$ \\
$16: 1 \omega 7 / \omega 9$ & $14 \cdot 8$ & $13 \cdot 8$ & $7 \cdot 4$ & $7 \cdot 4$ \\
$16: 0$ & $10 \cdot 6$ & $20 \cdot 8$ & $17 \cdot 3$ & $28 \cdot 7$ \\
$16: 0$ iso & - & - & $1 \cdot 8$ & - \\
$16: 0$ 2-OH & - & - & - & $10 \cdot 4$ \\
$17: 0$ cyclo 7,8 & $2 \cdot 2$ & - & - & - \\
$17: 0$ & $1 \cdot 7$ & - & $1 \cdot 8$ & - \\
$17: 1 \omega 6 c$ & - & $1 \cdot 0$ & $1 \cdot 5$ & - \\
$17: 1 \omega 8 c$ & - & - & $1 \cdot 1$ & - \\
$18: 1 \omega 7$ & $57 \cdot 5$ & $40 \cdot 7$ & $57 \cdot 7$ & $41 \cdot 9$ \\
$18: 0$ & $0 \cdot 9$ & - & - & - \\
$19: 0$ cyclo 8,9 & - & - & - & $1 \cdot 5$ \\
\hline
\end{tabular}


more precisely, that it could be included in the phylogenetic lineage comprising the freshwater and brackish water representatives of the group Caulobacter-BrevundimonasAsticcacaulis (Fig. 2). The novel isolate from tundra wetland peat was most closely related to the three known representatives of the genus Asticcacaulis, i.e. A. excentricus DSM $4724^{\mathrm{T}}$ (95\% 16S rRNA gene sequence similarity), A. taihuensis T3$\mathrm{B7}^{\mathrm{T}}$ (98\%) and A. biprosthecium DSM $4723^{\mathrm{T}}$ (98\%). The DNA G $+C$ content of strain Z- $0023^{\mathrm{T}}$ was $60.4 \mathrm{~mol} \%$ and the genome size was $2.5 \times 10^{9} \mathrm{Da}$. Levels of DNA-DNA hybridization between strain $\mathrm{Z}-0023^{\mathrm{T}}$ and A. biprosthecium DSM $4723^{\mathrm{T}}$ and $A$. excentricus DSM $4724^{\mathrm{T}}$ were 40 and $35 \%$, respectively.

The combined morphological and genotypic characteristics reported above indicate that strain $\mathrm{Z}-0023^{\mathrm{T}}$ belongs to the genus Asticcacaulis. However, compared with A. biprosthecium and $A$. excentricus, the novel strain has greater tolerance to low temperatures and low $\mathrm{pH}$, but has higher sensitivity to dissolved salts. We were not able to compare temperature and $\mathrm{pH}$ growth ranges of strain $\mathrm{Z}-0023^{\mathrm{T}}$ with those of A. taihuensis, as these characteristics have not been reported for the latter bacterium. The unique morphological feature of strain $\mathrm{Z}-0023^{\mathrm{T}}$ was the presence of bell-shaped sheaths that appeared on cells grown at low temperatures. Strain Z-0023 $3^{\mathrm{T}}$ also differed from all three recognized species of the genus Asticcacaulis with regard to the assimilation of several substrates (Table 2) and the absence of fatty acid 12:13-OH in the FAME profile. Thus we propose a novel species, Asticcacaulis benevestitus sp. nov., to accommodate this prosthecate bacterium from tundra wetland peat. The major characteristics differentiating this novel species from recognized species of the genus Asticcacaulis are summarized in Table 2.
Table 2. Major characteristics that distinguish strain Z$0023^{\top}$ from other species of the genus Asticcacaulis

Taxa: 1, Z- $0023^{\mathrm{T}} ; 2$, A. excentricus (data taken from Poindexter, 1964); 3, A. biprosthecium (data taken from Pate et al., 1973); 4, A. taihuensis (data taken from Liu et al., 2005). v, Variable; ND, not determined.

\begin{tabular}{|lcccc|}
\hline Characteristic & $\mathbf{1}$ & $\mathbf{2}$ & $\mathbf{3}$ & $\mathbf{4}$ \\
\hline Number of prosthecae per cell & 1 & 1 & $1-2$ & 1 \\
Presence of a sheath & + & - & - & - \\
Utilization of: & & & & \\
$\quad$ Pyruvate & - & + & + & $\mathrm{ND}$ \\
L-Arabinose & + & $\mathrm{v}$ & - & + \\
Sucrose & + & + & - & + \\
D-Mannose & - & + & - & + \\
D-Cellobiose & - & $\mathrm{ND}$ & $\mathrm{ND}$ & + \\
D-Melibiose & - & $\mathrm{ND}$ & $\mathrm{ND}$ & + \\
Temperature optimum $\left({ }^{\circ} \mathrm{C}\right)$ & $15-20$ & 30 & 30 & $\mathrm{ND}$ \\
pH optimum & $5 \cdot 6-6 \cdot 0$ & $6 \cdot 5$ & $7 \cdot 2$ & $\mathrm{ND}$ \\
NaCl requirement for growth & - & + & + & $\mathrm{ND}$ \\
Growth at $>2 \%(\mathrm{w} / \mathrm{v}) \mathrm{NaCl}$ & - & + & + & - \\
Presence of $12: 1$ 3-OH fatty acid & - & + & + & + \\
DNA G $+\mathrm{C}$ content $(\mathrm{mol} \%)$ & $60 \cdot 4$ & 55 & 61 & 59 \\
\hline
\end{tabular}

\section{Description of Asticcacaulis benevestitus sp. nov.}

Asticcacaulis benevestitus (be.ne.vesti'tus. L. adv. bene well; L. part. adj. vestitus clothed/clad; N.L. masc. part. adj. benevestitus well clad).

Cells are rod-shaped, Gram-negative, $0 \cdot 5-0 \cdot 7$ by $1 \cdot 4-2 \cdot 0 \mu \mathrm{m}$. Reproduces by binary fission. Undergoes a

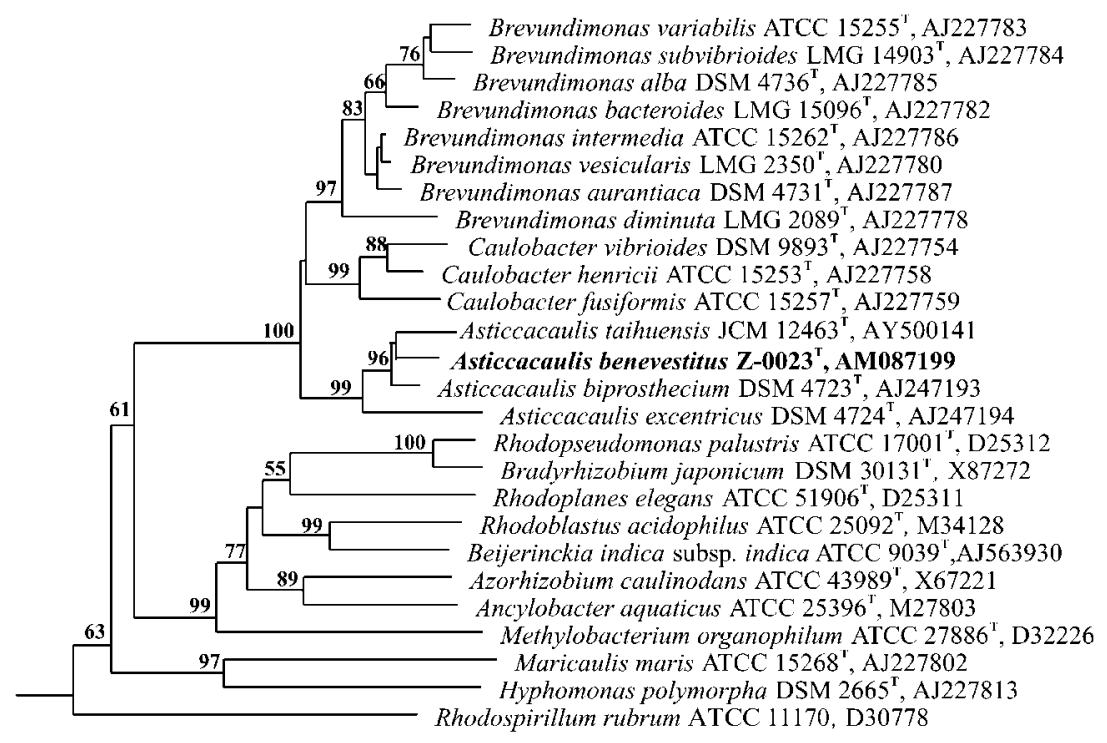

0.10
Fig. 2. Neighbour-joining tree based on 16S rRNA gene sequences showing the phylogenetic position of strain Z-0023 ${ }^{\top}$ in relation to Asticcacaulis biprosthecium, Asticcacaulis excentricus, Asticcacaulis taihuensis, prosthecate bacteria of the genera Caulobacter, Brevundimonas and Maricaulis, and some other representative members of the Alphaproteobacteria. Bootstrap values (1000 data resamplings) of $>50 \%$ are shown. The 16S rRNA gene sequence of the gammaproteobacterium Pseudomonas stutzeri (AF143245) was used as an outgroup (not shown). Bar, $0 \cdot 1$ substitutions per nucleotide position. 
dimorphic life cycle during which a sessile cell with one excentral, subpolar prostheca divides to give rise to a motile cell with a single, polar flagellum. A single, non-adhesive prostheca $0 \cdot 10-0 \cdot 15 \mu \mathrm{m}$ in diameter arises from a subpolar site. At temperatures below $10{ }^{\circ} \mathrm{C}$ most prosthecate cells are embedded in a conical bell-shaped sheath, which is attached to the cell at the point of juncture of prostheca and cell. Colonies are opaque, white, smooth, circular, convex with an entire edge, and $1-2.5 \mathrm{~mm}$ in diameter after 7 days growth at $20^{\circ} \mathrm{C}$ on PYG medium. Chemo-organotrophic aerobe. Carbon sources include glucose, sucrose, xylose, maltose, galactose, arabinose, lactose, fructose, ethanol, acetate, malate, fumarate, succinate, raffinose, rhamnose and trehalose. Yeast extract is required for growth. Temperature range for growth is $4-28{ }^{\circ} \mathrm{C}$ (optimum at $15-20^{\circ} \mathrm{C}$ ). Growth occurs between $\mathrm{pH} 4 \cdot 5$ and $8 \cdot 3$, with an optimum at $\mathrm{pH} 5 \cdot 6-6 \cdot 0 . \mathrm{NaCl}$ is not required for growth and is tolerated up to a concentration of $2 \cdot 0 \%(\mathrm{w} / \mathrm{v})$. Susceptible to antibiotics that inhibit prokaryotic protein synthesis. The major fatty acid is $18: 1 \omega 7 c$ and the major phospholipids are phosphatidylglycerols. The DNA G+C content is $60.4 \mathrm{~mol} \%$. Genome size is $2.5 \times 10^{9} \mathrm{Da}$.

The type strain, Z-0023 ${ }^{\mathrm{T}}\left(=\mathrm{DSM} 16100^{\mathrm{T}}=\right.$ ATCC BAA$896^{\mathrm{T}}$ ), was isolated from a tundra wetland in the Vorkuta region, northern Russia.

\section{Acknowledgements}

This research was supported by the Federal Scientific-Technical Program 'Biogenic sinks, sources, and reservoirs of the greenhouse gases' no. 43.016.11.1622, the Russian Science Support Foundation and the programme 'Molecular and Cell Biology' of the Russian Academy of Sciences.

\section{References}

Abraham, W.-R., Meyer, H., Lindholst, S., Vancanneyt, M. \& Smit, J. (1997). Phospho- and sulfolipids as biomarkers of Caulobacter, Brevundimonas and Hyphomonas. Syst Appl Microbiol 20, 522-539.

Abraham, W.-R., Hesse, C. \& Pelz, O. (1998). Ratios of carbon isotopes in microbial lipids as an indicator of substrate usage. Appl Environ Microbiol 64, 4202-4209.

Abraham, W.-R., Strömpl, C., Meyer, H. \& 8 other authors (1999). Phylogeny and polyphasic taxonomy of Caulobacter species. Proposal of Maricaulis gen. nov. with Maricaulis maris (Poindexter) comb. nov. as the type species, and emended description of the genera Brevundimonas and Caulobacter. Int J Syst Bacteriol 49, 1053-1073.

Abraham, W.-R., Strömpl, C., Vancanneyt, M., Lünsdorf, H. \& Moore, E. R. B. (2001). Determination of the systematic position of the genus Asticcacaulis Poindexter by a polyphasic analysis. Int J Syst Evol Microbiol 51, 27-34.

Belyaev, S. S. (1968). Distribution of the caulobacter group of bacteria in the Volga-Don reservoirs. Microbiology (English translation of Mikrobiologiya) 36, 130-133.

Bligh, E. G. \& Dyer, W. J. (1959). A rapid method for total lipid extraction and purification. Can J Biochem Physiol 37, 911-917.

Dedysh, S. N., Panikov, N. S. \& Tiedje, J. M. (1998). Acidophilic methanotrophic communities from Sphagnum peat bogs. Appl Environ Microbiol 64, 922-929.
De Ley, J., Cattoir, H. \& Reynaerts, A. (1970). The quantitative measurement of DNA hybridization from renaturation rates. Eur $J$ Biochem 12, 133-142.

Henrici, A. T. \& Johnson, D. E. (1935). Studies on fresh water bacteria. II. Stalked bacteria, a new order of schizomycetes. J Bacteriol 30, 61-93.

Lane, D. J. (1991). 16S/23S rRNA sequencing. In Nucleic Acid Techniques in Bacterial Systematics, pp. 115-175. Edited by E. Stackebrandt \& M. Goodfellow. Chichester: Wiley.

Lapteva, N. A. (1987). Ecological characteristics of Caulobacter incidence in fresh-water basins. Microbiology (English translation of Mikrobiologiya) 56, 677-684.

Larson, R. J. \& Pate, J. L. (1975). Growth and morphology of Asticcacaulis biprosthecum in defined media. Arch Microbiol 106, 147-157.

Liu, Z.-P., Wang, B.-J., Liu, S.-J. \& Liu, Y.-H. (2005). Asticcacaulis taihuensis sp. nov., a novel stalked bacterium isolated from Taihu Lake, China. Int J Syst Evol Microbiol 55, 1239-1242.

Ludwig, W., Strunk, O., Westram, R. \& 29 other authors (2004). ARB: a software environment for sequence data. Nucleic Acids Res 32, 1363-1371.

Lysenko, A. M., Gal'chenko, V. F. \& Chernykh, N. A. (1988). Taxonomic study of obligate methanotrophic bacteria using the DNA-DNA hybridization technique. Microbiology (English translation of Mikrobiologiya) 57, 653-658.

Nikitin, D. I., Vasilyeva, L. V. \& Lohmacheva, R. A. (1966). New and Rare Forms of Soil Microorganisms. Moscow: Nauka.

Osterhout, G. J., Shull, V. H. \& Dick, J. D. (1991). Identification of clinical isolates of Gram-negative nonfermentative bacteria by an automated cellular fatty acid identification system. J Clin Microbiol 29, 1822-1830.

Owen, R. J., Lapage, S. P. \& Hill, L. R. (1969). Determination of base composition from melting profiles in dilute buffers. Biopolymers 7 , 503-516.

Pate, J. L., Porter, J. S. \& Jordan, T. L. (1973). Asticcacaulis biprosthecum sp. nov. Life cycle, morphology and cultural characteristics. Antonie van Leeuwenhoek J Microbiol Serol 39, 569-583.

Poindexter, J. S. (1964). Biological properties and classification of the Caulobacter group. Bacteriol Rev 28, 231-295.

Poindexter, J. S. (1981a). The Caulobacters: ubiquitous unusual bacteria. Microbiol Rev 45, 123-179.

Poindexter, J. S. (1981b). Oligotrophy. Fast and famine existence. Microb Ecol 5, 63-89.

Poindexter, J. S. (1999). Dimorphic prosthecate bacteria: the genera Caulobacter, Asticcacaulis, Hyphomicrobium, Pedomicrobium, Hyphomonas, and Thiodendron. In The Prokaryotes, 3rd edn. Edited by M. Dworkin, S. Falkow, E. Rosenberg, K.-H. Schleifer \& E. Stackebrandt. New York: Springer. http://link.springer-ny.com/link/service/books/ 10125.

Staley, J. T. (1968). New prosthecate freshwater bacteria. J Bacteriol 95, 1921-1942.

Staley, J. T., Konopka, A. E. \& Dalmasso, J. P. (1987). Spatial and temporal distribution of Caulobacter spp. in two mesotrophic lakes. FEMS Microbiol Ecol 45, 1-6.

Vasilyeva, L. V. \& Zavarzin, G. A. (1995). Dissipotrophs in the microbial community. Microbiology (English translation of Mikrobiologiya) 64, 198-202.

Yakimov, M. M., Giuliano, L., Denaro, R., Crisafi, E., Chernikova, T. N., Abraham, W.-R., Luensdorf, H., Timmis, K. N. \& Golyshin, P. N. (2004). Thalassolituus oleivorans gen. nov., sp. nov., a novel marine bacterium that obligately utilizes hydrocarbons. Int J Syst Evol Microbiol 54, 141-148. 